\title{
A New Species of Meristogenys (Anura: Ranidae) from Sarawak, Borneo
}

\section{$\operatorname{AUTHOR}(\mathrm{S})$ :}

Shimada, Tomohiko; Matsui, Masafumi; Nishikawa, Kanto; Koshiro, Eto

\section{CITATION:}

Shimada, Tomohiko ...[et al]. A New Species of Meristogenys (Anura: Ranidae) from Sarawak, Borneo. Zoological Science 2015, 32(5): 474484

\section{ISSUE DATE:}

2015-10

URL:

http://hdl.handle.net/2433/216905

\section{RIGHT:}

(C) 2015 Zoological Society of Japan 


\title{
A New Species of Meristogenys (Anura: Ranidae) from Sarawak, Borneo
}

\author{
Tomohiko Shimada $^{1 *}$, Masafumi Matsui ${ }^{2}$, Kanto Nishikawa ${ }^{2}$, and Koshiro Eto ${ }^{2,3}$ \\ ${ }^{1}$ Aichi University of Education, Kariya, Aichi 448-8542, Japan \\ ${ }^{2}$ Graduate School of Human and Environmental Studies, Kyoto University, \\ Sakyo, Kyoto 606-8501, Japan \\ ${ }^{3}$ The Kyoto University Museum, Sakyo, Kyoto 606-8501, Japan
}

\begin{abstract}
A cryptic Bornean torrent frog of the genus Meristogenys, which is divergent genetically and morphologically from all known congeners, is described from mountain streams of western Sarawak, East Malaysia (Borneo). The species occurs sympatrically with the type species of the genus, $M$. jerboa, but apparently differs from it in adult coloration and larval morphology, such as keratodont formulae and glands in tail fins. Females of the new species possess much larger and fewer eggs than in sympatric $M$. jerboa, suggesting significantly different reproductive traits between these species. A key to larvae of known species of the genus is provided.
\end{abstract}

Key words: Meristogenys penrissenensis sp. nov., mtDNA phylogeny, larval morphology, taxonomy, Borneo

\section{INTRODUCTION}

Meristogenys Yang, 1991, a ranid genus endemic to Borneo, is characterized by peculiar larvae that inhabit mountain torrents using a huge abdominal, suctorial disk (Inger, 1966). The first frog of this genus was reported as Hylorana jerboa by Günther (1872), from Matang, Sarawak, Borneo (East Malaysia). This species (as Rana or Amolops) was once thought to be widely distributed across a wide range of Borneo, including Sabah, Sarawak, and Kalimantan (Smith, 1925, 1931; Inger, 1966), as well as other parts of Southeast Asia, such as Myanmar (Boulenger, 1893, 1920), Philippines (de Elera, 1895), Malay Peninsula (Boulenger, 1912), Sumatra, Java (van Kampen, 1923), and Thailand (Taylor, 1962). However, at present, specimens from outside of Borneo have proven not to be members of Meristogenys, and there is no authentic record of this species outside of Borneo (Yang, 1991). Further, numerous cryptic species have been separated from this species (Inger and Gritis, 1983; Matsui, 1986; Matsui et al., 2010; Shimada et al., 2007, 2011a, b), and the distribution range of the 'true' $M$. jerboa, after these taxonomic splits, is thought to be restricted to southwestern corner of Sarawak (Inger and Stuebing, 2009).

In the genus Meristogenys, it is often the case that two or more species sympatrically inhabit a single stream (Shimada et al., 2007), but no congeneric species have been reported from the distribution area of the true $M$. jerboa. However, we found an unknown cryptic species coexisting with $M$. jerboa, and through molecular and morphological studies on adult

\footnotetext{
* Corresponding author. Tel. : :+81-566-26-2364;

Fax : +81-566-26-2364;

E-mail: shimadatom@gmail.com
}

Supplemental material for this article is available online.

doi:10.2108/zs140289 and larvae, we confirmed it to be distinct from M. jerboa and describe it below as a new species.

\section{MATERIALS AND METHODS}

Sampling was made in Sarawak (Fig. 1) during March 2009 and December 2013. After collecting specimens, we took tissues for later biochemical analysis and fixed the frogs as vouchers. Adult specimens were fixed in $10 \%$ formalin and later preserved in $70 \%$ ethanol. Larvae were fixed and preserved in $5 \%$ formalin. To avoid morphological change due to shrinkage, fixed posture, and insufficient fixation through high specimen density, we anesthetized larval specimens with acetone chloroform (chloretone) solution and fixed them on a flat space with sufficient amount of formalin. Assignment of metamorphs to larvae for the new species, as well as for congeners, was based upon analyses of mtDNA sequences (Shimada et al., 2007). Specimens examined are stored at the Sarawak Research Collections (SRC) and Graduate School of Human and Environmental Studies, Kyoto University (KUHE) (see Supplementary File).

\section{Molecular analysis}

We obtained DNA sequence data from the muscle samples preserved in $99 \%$ ethanol. We reconstructed phylogenetic trees from two data sets, as given below.

1. Approximately 450 base pairs (bp) of the partial sequences of mitochondrial 16S rRNA (16S) from 19 adults and seven larvae from surveyed area, combined with sequences of other Meristogenys species and outgroups (Fejervarya kawamurai and Pelophylax nigromaculatus), using the data in Shimada et al. (2011a).

2. Approximately $4900 \mathrm{bp}$ of mitochondrial $12 \mathrm{~S}$ rRNA (12S), 16S, NADH dehydrogenase subunits 1 and 2 (ND1 and ND2), and tRNAs (valin, leucine, isoleucine, glycine, methionine, and tryptophan) of a single specimen from each major lineage of surveyed samples, combined with sequences of other species and outgroups.

DNA was extracted using a standard phenol-chloroform extraction procedure. We used the primers shown in Shimada et al. (2011a) to amplify and sequence genomes. The polymerase chain reaction (PCR) cycling, precipitation, and sequencing procedures were identical to those described by Shimada et al. (2008). Newly 
obtained sequences were deposited in GenBank (LC055962LC055971). We subjected the data to two different methods of phylogenetic reconstruction: (1) maximum likelihood (ML) analysis using TreeFinder (Jobb, 2011), based on the substitution model derived from a model selection method in Kakusan4 (Tanabe, 2010); (2) Bayesian analysis using MrBayes (Huelsenbeck and Ronquist, 2001), with the model derived from Kakusan4 (Tanabe, 2010). We ran 10 million generations, sampled a tree every 100 generations, and discarded the initial one-fourth as burn-in. The confidential values of the $\mathrm{ML}$ tree were tested using bootstrap analyses (ML-BS) with 1000 replicates (Felsenstein, 1985). For Bayesian analysis, posterior probability (BPP) of each branch was used for the confidential value. Following Huelsenbeck and Hillis (1993), Leaché and Reeder (2002), and Matsui et al. (2006), we considered bootstrap values of $70 \%$ or larger and posterior probabilities of $95 \%$ or more to be statistically significant. For the voucher specimens used in the molecular analysis, see Supplementary File.

\section{Morphological analysis of adults}

For preserved adult specimens, we took the following 23 body measurements (Fig. 2), following Matsui (1984), Matsui et al. (2010), and Shimada et al. (2011a), to the nearest $0.1 \mathrm{~mm}$ with dial calipers: (1) snout-vent length (SVL); (2) head length (HL), from tip of snout to hind border of angle of jaw (not measured parallel with the median line); (3) snout-nostril length (S-NL); (4) nostril-eye length (N-EL); (5) snout length (SL); (6) eye length (EL); (7) tympanum-eye length (T-EL); (8) tympanum diameter measured vertically (TDv); (9) tympanum diameter measured horizontally (TDh); (10) head width (HW); (11) internarial distance (IND); (12) interorbital distance (IOD); (13) upper eyelid width (UEW); (14) forelimb length (FLL); (15) lower arm length (LAL), from elbow joint to tip of third finger, measured with forearm stretched straight and flexed perpendicular to upper arm; (16) hand length (HAL), from proximal edge of outer palmer tubercle to tip of third finger; (17) hindlimb length (HLL); (18) thigh length (THIGH), from center of vent to knee joint, measured with thigh flexed perpendicular to body axis and folding knee; (19) tibia length (TL); (20) foot length (FL), from proximal end of inner metatarsal tubercle to tip of fourth toe; (21) inner metatarsal tubercle length (IMTL); (22) third finger disk diameter (3FDW); and

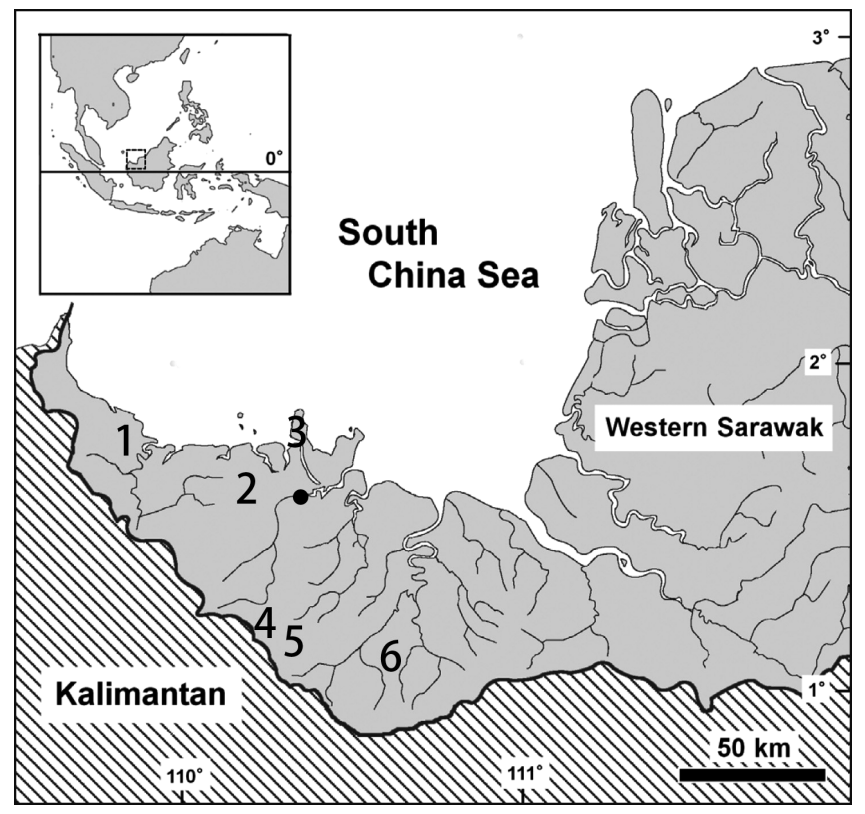

Fig. 1. Map of Sarawak showing sampling localities; 1 Gading, 2 Matang, 3 Santubong, 4 Mt. Penrissen, 5 Annah Rais, 6 Ranchan. Closed circle $=$ Kuching city.
(23) fourth toe disk diameter (4TDW). Of these, measurements for FLL and HLL were taken by forcing the limbs into an extended straight position as shown in Fig. 2.

\section{Morphological analysis of larvae}

For larvae, the following 14 measurements (Fig. 2) were taken to the nearest $0.01 \mathrm{~mm}$ with dial calipers under a binocular microscope; (1) total length (TTL); (2) head-body length (HBL); (3) maximum head-body width (HBW); (4) maximum head-body depth (HBD); (5) sucker width (SUW); (6) sucker length (SUL) from anterior end of abdominal disk to its posterior end; (7) snout and sucker length (SSL); from snout to posterior end of abdominal disk; (8) oral disk width (ODW); (9) snout width (SNW); (10) eyeball diameter (ED); (11) eye-snout distance (ESD); (12) IND; (13) IOD; (14) maximum tail depth (TLD). Tail length (TLL) was calculated subtracting $\mathrm{HBL}$ from TTL. All variables were measured in specimens preserved in $5 \%$ formalin at least one month. Measurements were made mainly following Inger (1985), and staging followed Gosner's (1960) table. We followed the terminology of McDiarmid and Altig (1999) for the oral apparatus and that of Shimada et al. (2007) and Shimada et al. (2011a) for other characters.

\section{RESULTS}

\section{Phylogenetic analysis using short fragments of $16 \mathrm{~S}$}

We obtained $454 \mathrm{bp}$ of mtDNA, of which 121 bp were variable and $61 \mathrm{bp}$ were parsimony informative. The best substitution model based on AIC was J2 model with a Gamma (G) shape parameter. The likelihood values of the $\mathrm{ML}$ tree and the marginal likelihoods for Bayesian analysis (arithmetic mean) were $-\ln \mathrm{L}=1696.13$ and 1716.10, respectively. The results from two phylogenetic inferences were slightly different, but the nodes that were significantly supported did not conflict with each other (Fig. 3).

Monophyly of Meristogenys sp. and M. jerboa was supported with moderate support values (ML bootstrap value $[\mathrm{ML}-\mathrm{BS}]=81 \%$, Bayesian posterior probability $[\mathrm{BPP}]=$ 0.90). In this clade, both of Meristogenys sp. (ML-BS $=97 \%$, $\mathrm{BPP}=0.99)$ and $M$. jerboa $(\mathrm{ML}-\mathrm{BS}=86 \%, \mathrm{BPP}=0.99)$ formed a well-supported clade. Meristogenys jerboa contains two major lineages (lineages $A$ and $B$ ). The lineage $A$ was detected in 13 samples (all samples from Gading, Matang, and Santubong, and each one sample from Mt. Penrissen and Annah Rais), sharing nearly identical sequences (a single substitution was found in a sample from Matang). The lineage B was detected in six samples (all samples from Ranchan, and each one sample from Mt. Penrissen and Annah Rais), sharing an identical sequence. In Mt. Penrissen and Annah Rais, both of lineages A and B were detected. Phylogenetic relationships among these clades and other known species of Meristogenys were unresolved.

\section{Phylogenetic analysis using long fragments of mtDNA}

We obtained $4968 \mathrm{bp}$ of mtDNA, of which $1970 \mathrm{bp}$ were variable and $1221 \mathrm{bp}$ were parsimony informative. The best substitution model based on $\mathrm{AIC}$ was the $\mathrm{J} 2+\mathrm{G}$ for $12 \mathrm{~S}$ and ND2, J3 + G for tRNA, and the general time reverse (GTR) model with Gamma shape parameter for $16 \mathrm{~S}$ and ND1. The likelihood values of the ML tree and the marginal likelihoods for Bayesian analysis (arithmetic mean) were $-\mathrm{ln} \mathrm{L}=$ $26,381.62$, and 26,393.43, respectively. The results from two phylogenetic inferences were slightly different, but the nodes with significant supports did not conflict with each other (Fig. 4). 


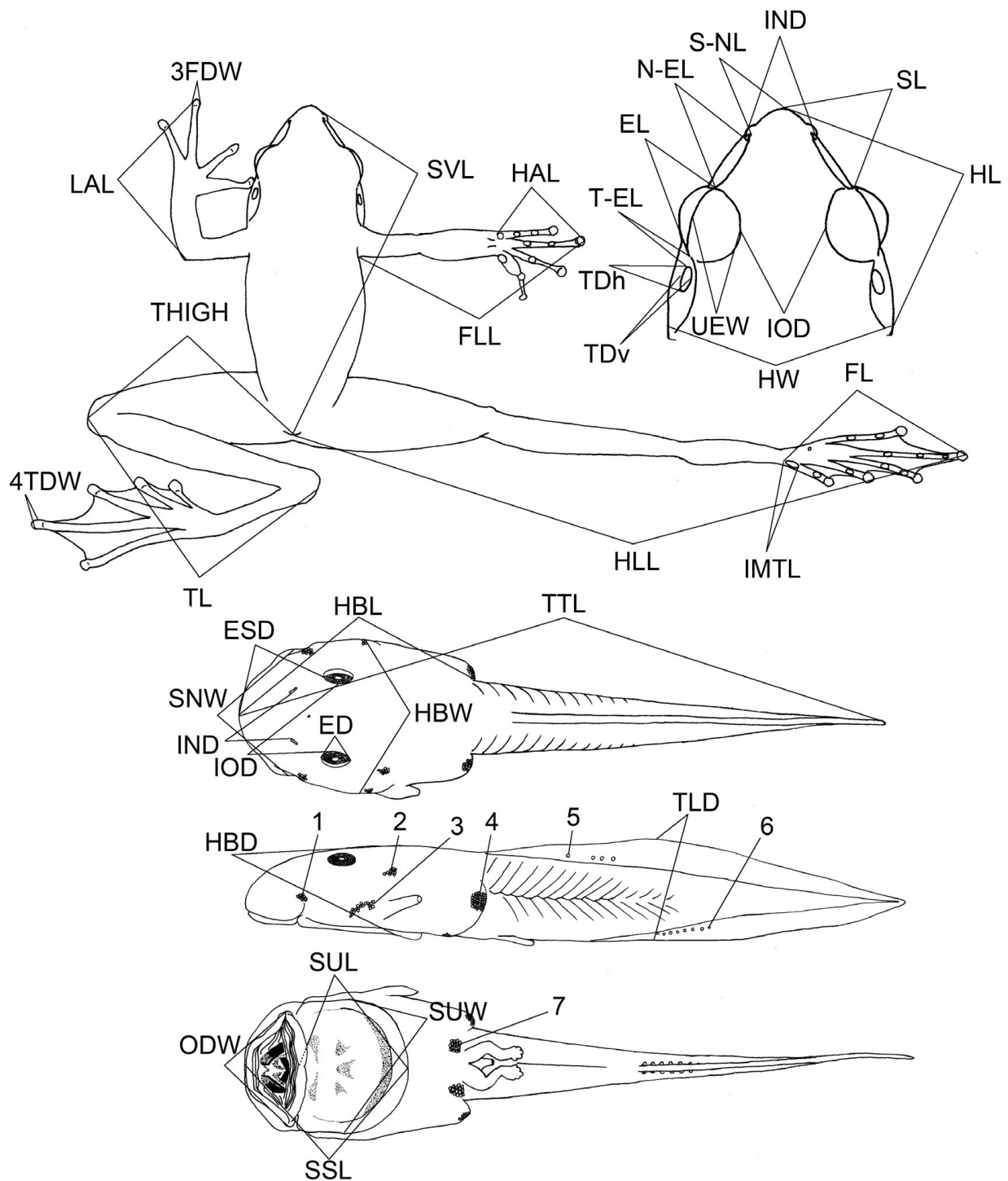

Fig. 2. Character dimensions of adult and larval Meristogenys. Glandular clusters are also shown in larval figure. 1: infraorbital cluster; 2: postorbital cluster; 3: prespiracular cluster; 4: posterior midlateral cluster; 5: dorsal fin cluster; 6: ventral fin cluster; and 7: abdominal cluster.

The species of Meristogenys formed a fully supported clade with respect to outgroups (ML-BS $=100 \%, \mathrm{BPP}=1.00$ ). Among them, M. kinabaluensis was firstly split from other species of Meristogenys (the M. jerboa species group [Matsui, 1986]) with full support values (ML-BS $=100 \%$, BPP $=$ 1.00). In the clade of the $M$. jerboa species group, the unnamed form described below formed a sister clade (ML$\mathrm{BS}=100 \%, \mathrm{BPP}=1.00$ ) to $M$. jerboa, which contained two relatively remote lineages (lineages $A$ and $B$ ). Meristogenys dyscritus, M. maryatiae, M. orphnocnemis, M. stigmachilus, $M$. poecilus, and $M$. whiteheadi formed another large clade (ML-BS $=95 \%$, BPP $=1.00$ ), in which $M$. poecilus was first split from others $(\mathrm{ML}-\mathrm{BS}=70 \%, \mathrm{BPP}=0.98)$. Among other species in this large clade, $M$. dyscritus and $M$. orphnocnemis formed a well-supported clade (ML-BS $=100 \%, B P P=1.00$ ), which was sister-taxon to $M$. maryatiae (ML-BS $=97 \%$, $\mathrm{BPP}=1.00)$. Meristogenys whiteheadi and $M$. stigmachilus formed a well-supported clade in the Bayesian inference
$(\mathrm{BPP}=0.97)$, although the confidential value of this clade was weak in the $\mathrm{ML}$ analysis $(\mathrm{ML}-\mathrm{BS}=63 \%)$.

The genetic distances between the unnamed form and its sister taxon, $M$. jerboa (p-distance: $4.2-4.6 \%$ in $16 \mathrm{~S}$ and $11.4-11.6 \%$ in ND1; Table 1) are comparable to other interspecific differences in this genus (e.g., M. orphnocnemis vs. $M$. dyscritus, $4.9-5.7 \%$ in $16 S$ and $9.6-10.5 \%$ in ND1; $M$. whiteheadi vs. $M$. stigmachilus, $4.7-4.8 \%$ in $16 \mathrm{~S}$ and $10.3-$ $10.4 \%$ in ND1). Judging from the relatively large genetic distances, along with morphological differences shown below, it is sure that the unnamed form is a distinct species, which we describe as a new taxon as follows:

\section{Meristogenys penrissenensis sp. nov. \\ (Fig. 5A)}

\section{Diagnosis}

A small form of the $M$. jerboa species group; male $39.4 \mathrm{~mm}$ SVL (snout-vent length), female $70.2-73.3 \mathrm{~mm}$; head narrow, width relative to SVL 31.4-35.2\%; eyes moderate, length relative to SVL $14.9-15.4 \%$ in males, diameter subequal to snout; iris bicolored, upper and lower area greenish yellow, bordered with red in between; legs long, length of tibia relative to SVL 72.3-79.7\%; ventral surface of tibia without heavy pigmentation; rear of thigh dark brown mottled with irregular light spots; web well developed, broad web reaching disk on all toes; ova pigmented; larvae with the keratodont formula $7(4-7) / 8(1)$; lower jaw sheaths divided; no glands on tail fins.

\section{Etymology}

The specific name is derived from the Mount Penrissen, whose peak is located about $2 \mathrm{~km}$ south of the type locality.

\section{Holotype}

KUHE 48520, an adult male from a stream of the northern slope of Mt. Penrissen, crossing Jalan Puncak Borneo (Borneo Heights Road) close to Borneo Highlands Resort, Padawan, Kuching Division, western Sarawak, East Malaysia $\left(1.08^{\prime} 32^{\prime \prime} \mathrm{N}, 110.13^{\prime} 38^{\prime \prime} \mathrm{E}, 460 \mathrm{~m}\right.$ a.s.I.), collected on 19 December 2013 by M. Matsui, K. Nishikawa, and T. Shimada. 


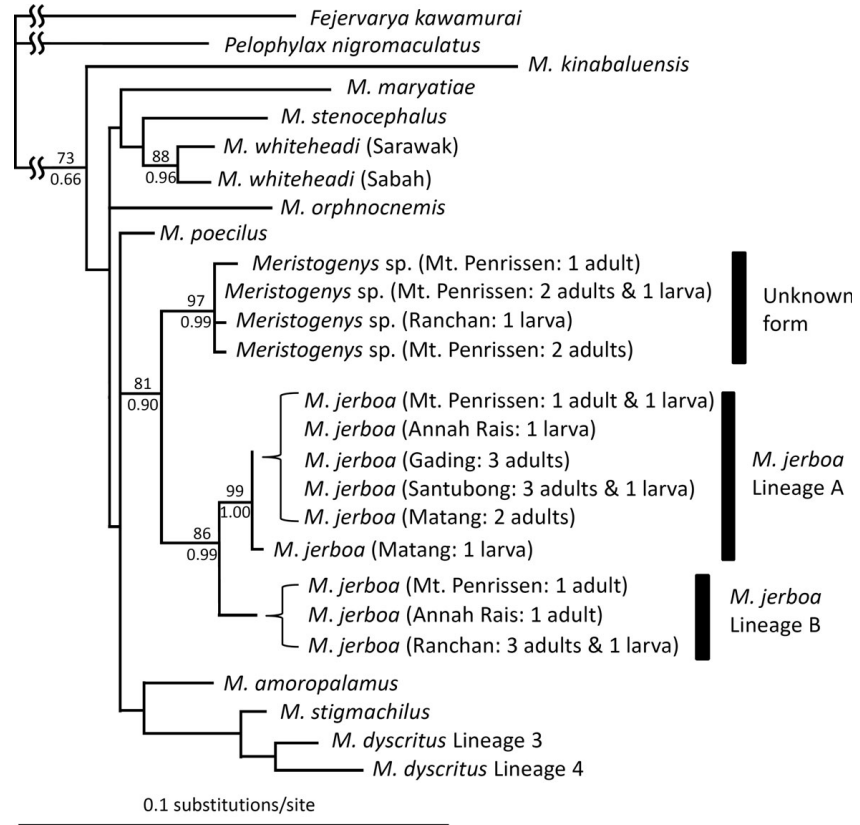

Fig. 3. A maximum likelihood tree of $454 \mathrm{bp}$ of mitochondrial $16 \mathrm{~S}$ rRNA for samples of Meristogenys sp. and $M$. jerboa from western Sarawak and representative congeneric members. Numbers above/ below branches represent bootstrap supports for $\mathrm{ML}$ inference (MLBS) and Bayesian posterior probability (BPP).

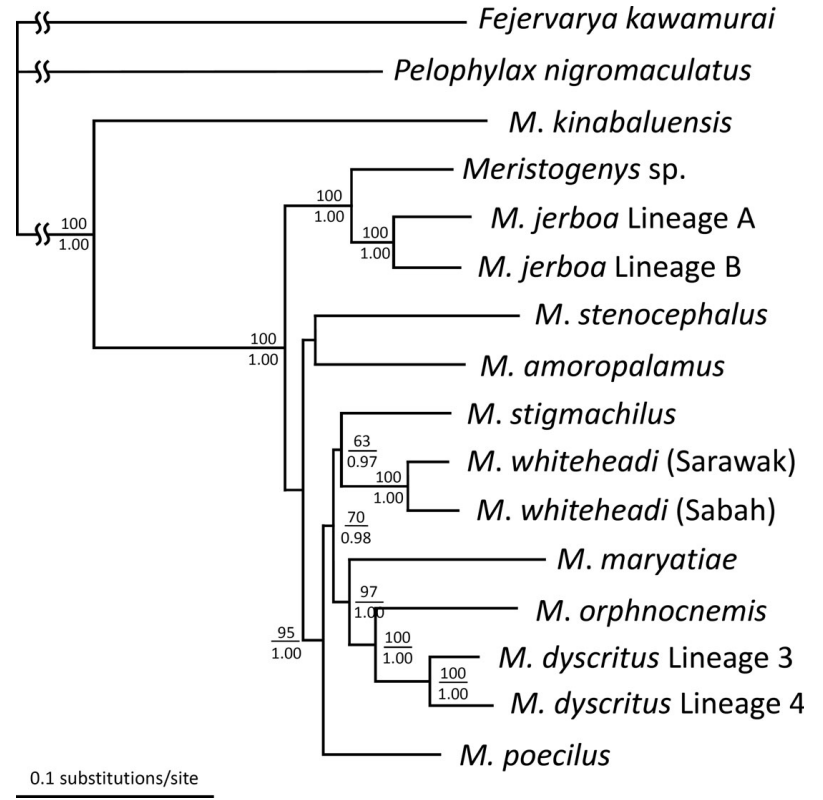

Fig. 4. A maximum likelihood tree of $4968 \mathrm{bp}$ of mitochondrial $12 \mathrm{~S}$ rRNA to ND2 region for major lineages of Meristogenys. Confidence values as in Fig. 2.

Table 1. Mean uncorrected p-distances (\%) among major lineages of Meristogenys for 16S rRNA (above diagonal) and ND1 (bellow diagonal). Shaded columns indicate distances between an unidentified sample from Mt. Penrissen and other congeneric species.

\begin{tabular}{lcccccccccccccc}
\hline & 1 & 2 & 3 & 4 & 5 & 6 & 7 & 8 & 9 & 10 & 11 & 12 & 13 & \multicolumn{1}{c}{14} \\
\hline 1. Meristogenys sp. & - & 4.2 & 4.6 & 5.5 & 5.9 & 6.1 & 7.7 & 6.3 & 7.1 & 6.3 & 4.8 & 5.2 & 6.8 & 10.3 \\
2. M. jerboa Lineage A & 11.4 & - & 2.9 & 6.1 & 6.1 & 6.5 & 8.3 & 6.7 & 7.5 & 7.3 & 5.7 & 6.2 & 6.9 & 10.7 \\
3. M. jerboa Lineage B & 11.6 & 7.2 & - & 5.9 & 6.3 & 6.5 & 7.9 & 6.3 & 7.4 & 7.2 & 5.8 & 6.4 & 7.0 & 10.4 \\
4. M. poecilus & 14.0 & 13.0 & 13.2 & - & 4.2 & 4.1 & 6.2 & 5.4 & 6.0 & 6.0 & 4.3 & 5.1 & 6.7 & 10.0 \\
5. M. whiteheadi (Sarawak) & 13.6 & 13.5 & 13.6 & 10.5 & - & 2.2 & 6.7 & 5.6 & 6.3 & 5.9 & 4.7 & 5.6 & 6.7 & 9.7 \\
6. M. whiteheadi (Sabah) & 14.0 & 13.6 & 13.9 & 11.6 & 5.0 & - & 6.8 & 5.9 & 6.1 & 6.0 & 4.8 & 5.4 & 7.1 & 10.1 \\
7. M. maryatiae & 16.0 & 14.6 & 15.9 & 13.5 & 13.1 & 13.5 & - & 7.1 & 7.3 & 7.2 & 6.8 & 6.8 & 7.6 & 11.9 \\
8. M. orphnocnemis & 14.6 & 15.1 & 14.5 & 13.0 & 12.0 & 12.5 & 14.2 & - & 5.7 & 4.9 & 5.6 & 6.1 & 7.0 & 10.6 \\
9. M. dyscritus Lineage 3 & 13.9 & 13.9 & 14.3 & 10.0 & 10.5 & 10.9 & 12.7 & 10.5 & - & 3.0 & 6.3 & 6.0 & 7.5 & 9.9 \\
10. M. dyscritus Lineage 4 & 13.3 & 12.7 & 13.3 & 11.3 & 10.3 & 10.9 & 12.7 & 9.6 & 5.7 & - & 6.0 & 5.6 & 7.2 & 9.6 \\
11. M. stigmachilus & 14.5 & 14.0 & 14.1 & 11.5 & 10.4 & 10.3 & 13.5 & 11.9 & 11.4 & 10.5 & - & 5.2 & 6.0 & 10.5 \\
12. M. amoropalamus & 14.0 & 14.3 & 15.0 & 13.4 & 11.8 & 12.3 & 14.4 & 14.0 & 11.6 & 12.0 & 12.5 & - & 6.2 & 9.9 \\
13. M. stenocephalus & 14.2 & 12.5 & 13.2 & 12.8 & 13.0 & 12.9 & 15.3 & 14.6 & 14.3 & 13.8 & 13.5 & 14.4 & - & 10.7 \\
14. M. kinabaluensis & 19.7 & 18.7 & 18.9 & 18.3 & 20.9 & 21.3 & 19.3 & 21.5 & 19.7 & 19.7 & 19.6 & 20.6 & 19.1 & - \\
\hline
\end{tabular}

\section{Paratypes}

All paratypes from Mt. Penrissen: SRC 00155 (juvenile, former KUHE 55489) from Batu Panggah, collected on 13 March 2013 by K. Nishikawa; KUHE 54464 (adult female) from Kalimantan Trail, collected on 20 February 2012 by K. Nishikawa; KUHE 55642 (adult female) from Batu Panggah, collected on 12 March 2013 by K. Nishikawa; KUHE 53912 (adult female) from Kalimantan Trail, collected on 2 September 2010 by K. Eto; KUHE 48562 (adult female) data same as the holotype; KUHE 48565 (adult male) from the type locality collected by M. Matsui, K. Nishikawa, and T. Shimada on 21 December 2013.

\section{Referred specimens}

KUHE unnumbered 49 tadpoles collected from the type locality on 19 December 2013. KUHE unnumbered seven tadpoles collected from a stream in the golf course of the Borneo Highlands Resort (870 m a.s.l., 2.2 $\mathrm{km}$ upstream of the type locality) on 21 December 2013. KUHE unnumbered three tadpoles collected from a stream in Taman Rekreasi Ranchan Serian (60 $\mathrm{m}$ a.s.l., $40 \mathrm{~km}$ east to the type locality), Padawan, Kuching Division, western Sarawak, East Malaysia. All larval specimens were collected by $\mathrm{M}$. Matsui, $\mathrm{K}$. Nishikawa, and T. Shimada.

\section{Description of holotype (measurements in millimeters)}

Body moderately slender (Fig. 5A), SVL 39.4; head triangular, longer (15.9) than wide (12.4); snout moderately short (7.4), pointed at tip in dorsal view, projecting in profile, projecting beyond lower jaw; canthus sharp, constricted; lore slightly oblique, concave; nostril lateral, below canthus, distinctly closer to tip of snout (S-NL 2.6) than to eye (N-EL 3.9); internarial distance (3.9) wider than interorbital (3.4), latter narrower than upper eyelid (4.0); eye elevated, diameter (5.9) much larger than eye-nostril; pupil horizontal; tym- 


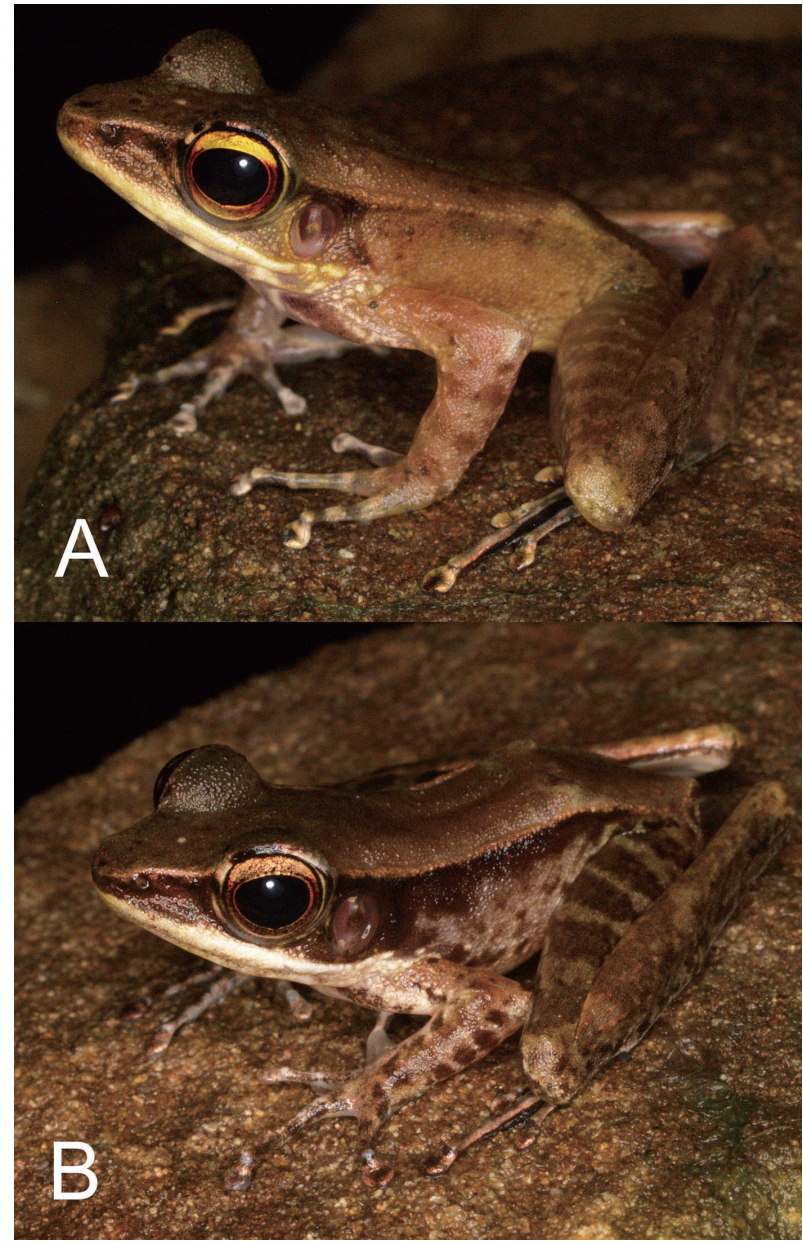

Fig. 5. Male holotype (KUHE 48520) of Meristogenys penrissenensis sp. nov. (A) and a sympatric male (KUHE 48515) of $M$. jerboa in life (B).

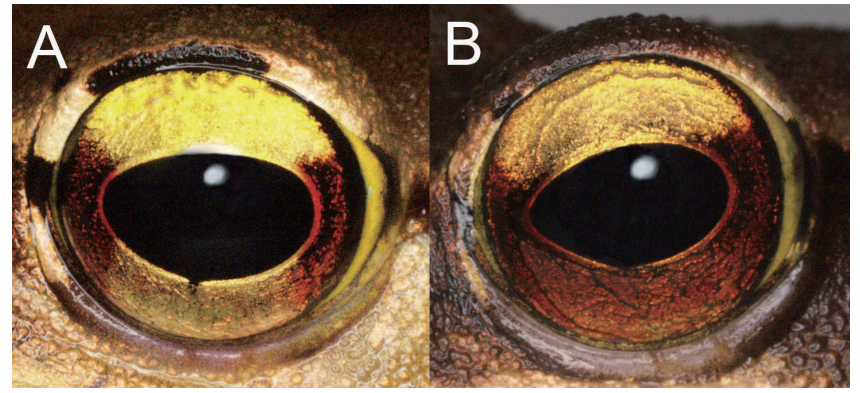

Fig. 6. Iris of a female paratype (KUHE 48562) of Meristogenys penrissenensis sp. nov. (A) and a female (KUHE 48689) of $M$. jerboa (B).

panum distinct, length (TDv 2.9; TDh 2.8) half of eye diameter and separated from eye by approximately half of tympanum diameter (T-EL 1.6); pineal spot visible, on line connecting anterior corners of orbits; vomerine teeth in short, slightly oblique groups, three to four teeth per group, separated by one-third length of one group from each other and by about same length of one group from choana, groups on line connecting rear rims of choanae; tongue deeply notched, without papilla; paired subgular vocal sacs form gular pouches at corners of throat; vocal openings just inside jaw commissures.

Fingers slender, first finger slightly longer than second, length of first (5.3; measured from distal edge of inner palmer tubercle), subequal to diameter of eye; fourth finger much longer than second; tips of fingers expanded into disks having circummarginal grooves; disc of second finger (1.1) larger than that of first finger (0.8), but smaller than those of third (1.6) and fourth (1.2) fingers; no webs between fingers; no fringes of skin along fingers; subarticular tubercles oval and distinct; distinct inner and two indistinct, elongate outer palmer tubercles; no supernumerary metacarpal tubercles.

Hindlimb long (86.4), about three times length of forelimb (28.4); tibia long (29.4), heels overlapping when limbs are held at right angles to body; tibiotarsal articulation of adpressed limb reaching to far beyond tip of snout; foot (22.5) shorter than tibia; toe disks similar to those of fingers in shape and size (disk diameter of fourth toe 1.4); webbing between toes full, extending to disks of all toes; narrow fringes of skin along medial edge of first toe and outer edge of fifth toe from distal subarticular tubercle to base of disk; subarticular tubercles oval and distinct; an oval inner metatarsal tubercle, length (1.5) about one-fourth length of first toe (5.7; measured from distal end of inner metatarsal tubercle to tip of first toe) and slightly longer than distance from proximal edge of subarticular tubercle of first toe; a small, rounded outer metatarsal tubercle.

Dorsum shagreened; a low, indistinct dorsolateral fold; side of trunk coarsely granular; a weak fold above tympanum from eye; no rectal and axillary glands; no dermal ridge on tarsus; chest and abdomen smooth.

Cream-colored asperities forming a distinct nuptial pad covering dorsal and medial surface of the first finger from its base to subarticular tubercle, and dorsally to base of disk.

\section{Color}

In life dorsum pale brown with a few black spots on head (Fig. 5A); lores and upper lips light brown, without dark markings; iris bicolored, upper and lower one third of iris yellowish brown, bordered by reddish brown in between (Fig. $6 \mathrm{~A}$ ); tympanum surrounded by blackish brown band; tympanum purplish brown with lighter center; limbs marked dorsally with alternating light and dark brown cross bars, the lighter ones wider; rear of thigh dark brown mottled with irregular light spots; ventral surfaces of legs slightly darker, scatteredly dotted with dark brown; lower lip indistinctly barred with light brown; throat, chest and abdomen whitish except for light brown vocal sac; webs blackish brown. In preservative, reddish brown area of iris changed to dark gray and dorsal coloration has slightly faded, but otherwise no marked change in color or pattern has occurred.

\section{Variation}

Individual variation in size and body proportions is given in Table 2. Females (SVL $=70.2-73.3 \mathrm{~mm}$ ) are apparently larger than males $(S V L=39.4 \mathrm{~mm})$. Only two male and four female samples available limited statistical comparisons, but some dimensions relative to SVL seem to be sexually dimorphic. Males have larger values relative to SVL than females in eye length (14.9-15.4\% vs. 13.7-13.9\%), tympanum 
Table 2. Specimen numbers, snout-vent length (SVL in $\mathrm{mm}$, mean $\pm 2 S E$, followed by ranges in parenthesis) and percentage ratios (R) of each of the other character dimensions to SVL (medians, followed by ranges in parenthesis) in adult samples of Meristogenys penrissenensis sp. nov. and M. jerboa.

\begin{tabular}{|c|c|c|c|c|c|c|c|c|c|}
\hline & \multicolumn{5}{|c|}{ Adult male } & \multirow{2}{*}{\multicolumn{2}{|c|}{$\frac{\begin{array}{c}\text { Juvenile } \\
\text { female }\end{array}}{\text { M. penrissenensis }}$}} & \multicolumn{2}{|c|}{ Adult female } \\
\hline & \multirow{2}{*}{$\frac{\text { M. penrissenensis }}{\text { Mt. Penrissen }}$} & \multicolumn{4}{|c|}{ M. jerboa } & & & \multicolumn{2}{|c|}{ M. jerboa } \\
\hline & & Mt. Penrissen & Annah Rais & Ranchan & Santubong & $\begin{array}{c}\text { Mt. } \\
\text { Penrissen }\end{array}$ & Mt. Penrissen & Ranchan & Santubong \\
\hline$n$ & 2 & 19 & 6 & 3 & 4 & 1 & 4 & 4 & 2 \\
\hline SVL & 39.4 & $\begin{array}{c}38.4 \pm 1.58 \\
(34.1-40.9)\end{array}$ & $\begin{array}{c}37.2 \pm 0.64 \\
(36.1-38.2)\end{array}$ & $\begin{array}{c}35.7 \\
(34.5-36.9)\end{array}$ & $\begin{array}{c}37.9 \\
(35.1-39.8)\end{array}$ & 55.7 & $\begin{array}{c}71.6 \\
(70.2-73.3)\end{array}$ & $\begin{array}{c}62.2 \\
(60.5-64.6)\end{array}$ & $\begin{array}{c}63.2 \\
(61.7-64.8)\end{array}$ \\
\hline RHL & $40.2(40.1-40.3)$ & $40.5(38.1-43.1)$ & $40.8(39-41.3)$ & $41.1(41.0-42.0)$ & $41.5(40.7-42.4)$ & 40.2 & $40.4(39.9-40.9)$ & $39.4(38.8-40.2)$ & $41.2(41.0-41.4)$ \\
\hline RS-NL & $6.0(5.5-6.5)$ & $6.9(5.0-7.7)$ & $6.5(6.1-8.0)$ & $7.3(6.7-7.5)$ & $6.5(6.4-7.0)$ & 6.2 & $6.4(5.6-6.8)$ & $5.8(5.7-6.9)$ & $6.9(6.7-7.0)$ \\
\hline RN-EL & $9.5(9.1-9.8)$ & $9.5(8.1-10.7)$ & $9.5(9.1-9.9)$ & $9.5(8.9-10.2)$ & $9.3(9.2-10.1)$ & 8.5 & $8.8(8.7-9.2)$ & $9.2(8.6-9.5)$ & $9.2(8.8-9.7)$ \\
\hline RSL & $17.6(16.4-18.7)$ & $17.4(16.3-18.7)$ & $17.4(16.8-17.7)$ & $17.6(17.0-17.9)$ & $17.2(17.0-17.9)$ & 15.0 & $16.2(15.9-17.5)$ & $16.5(16.0-17.0)$ & $17.8(17.6-18.0)$ \\
\hline REL & $15.2(14.9-15.4)$ & $15.7(14.9-17.7)$ & $15.7(14.1-15.8)$ & $15.6(15.6-17.0)$ & $16.7(16.2-17.4)$ & 15.0 & $13.8(13.7-13.9)$ & $14.9(13.6-15.3)$ & $14.0(13.7-14.4)$ \\
\hline RT-EL & $3.8(3.5-4.0)$ & $2.4(1.8-3.5)$ & $2.3(1.8-3.1)$ & $2.9(2.5-3.4)$ & $2.3(1.6-2.6)$ & 3.8 & $4.1(3.9-4.6)$ & $3.2(2.5-3.6)$ & $3.8(3.7-4.0)$ \\
\hline RTDv & $8.1(7.3-8.8)$ & $9.6(8.0-10.5)$ & $9.8(9.0-10.7)$ & $9.7(9.4-10.4)$ & $9.1(8.7-9.7)$ & 6.9 & $5.9(5.3-6.1)$ & $6.5(6.2-6.6)$ & $6.8(6.7-6.9)$ \\
\hline RTDh & $8.5(7.1-9.8)$ & $10.0(8.5-11.6)$ & $10.5(9.9-10.9)$ & $9.7(9.4-12.1)$ & $9.0(8.3-9.2)$ & 5.9 & $5.3(4.9-5.7)$ & $6.1(5.6-6.9)$ & $5.7(5.5-5.8)$ \\
\hline RHW & 32.7 (31.4-34.0) & 32.7 (31.2-34.4) & 31.8 (31.4-33.2) & $33.0(31.9-34.0)$ & $34.2(33.4-35.4)$ & 35.2 & $34.5(34.3-35.0)$ & 33.1 (32.4-33.5) & $34.9(34.9-35.0)$ \\
\hline RIND & $10.0(9.8-10.1)$ & $10.2(9.1-11.1)$ & $9.9(9.1-10.2)$ & $9.8(9.2-10.0)$ & $10.0(8.7-10.8)$ & 10.7 & $9.7(9.5-10.2)$ & $9.0(8.5-9.5)$ & $9.3(8.7-9.8)$ \\
\hline RIOD & $8.3(8.1-8.6)$ & $8.8(7.8-9.7)$ & $8.7(8.0-9.4)$ & $8.3(8.1-9.8)$ & $8.3(7.7-8.9)$ & 8.4 & $8.5(7.9-8.9)$ & $8.2(7.8-8.4)$ & $9.2(8.9-9.5)$ \\
\hline RUEW & $10.0(9.8-10.1)$ & $10.0(9.0-11.2)$ & $9.9(9.6-10.8)$ & $10.7(10.6-11.6)$ & $10.3(10.1-11.0)$ & 9.1 & $9.4(9.2-9.5)$ & $9.6(9.0-10.2)$ & $9.9(9.5-10.3)$ \\
\hline RFLL & 72.9 (72.0-73.8) & $67.4(63.4-71.7)$ & 67.4 (66.4-69.3) & $66.1(64.6-71.7)$ & $69.5(68.7-71.8)$ & 68.2 & $69.0(65.4-69.4)$ & $63.0(62.6-64.7)$ & $65.8(63.8-67.7)$ \\
\hline RLAL & $54.6(54.3-55.0)$ & $52.9(49.7-55.7)$ & $53.6(51.2-55.6)$ & $53.3(53.3-55.3)$ & $51.8(50.4-52.2)$ & 55.2 & $53.6(52.5-54.7)$ & $48.6(47.9-49.2)$ & $50.4(49.5-51.4)$ \\
\hline RHAL & $30.0(29.4-30.7)$ & $30.2(27.4-32.1)$ & $29.3(28.7-31.5)$ & $30.0(29.2-31.5)$ & $29.8(28.8-30.9)$ & 29.2 & $29.6(29.3-30.0)$ & 26.9 (26.5-27.7) & $27.3(27.0-27.6)$ \\
\hline RHLL 2 & $216.2(213.1-219.2)$ & $220.3(212.3-228.2)$ & 220.6 (209.0-225.9) & $218.6(214.4-224.0)$ & $212.5(211.2-216.5)$ & 228.9 & $216.5(215.6-223.5)$ & 206.7 (197.0-212.2) & $212.0(209.5-214.4)$ \\
\hline RTHIGH & $63.4(61.9-64.9)$ & $63.8(60.4-66.5)$ & $64.7(63.4-66.2)$ & $63.9(61.4-65.3)$ & $61.9(60.5-62.2)$ & 67.5 & $63.9(63.5-66.5)$ & $61.9(58.8-63.8)$ & $64.4(64.1-64.6)$ \\
\hline RTL & $73.4(72.3-74.6)$ & $75.1(71.9-77.4)$ & $75.3(73.4-79.5)$ & 73.9 (73.6-75.9) & 72.5 (69.2-73.9) & 79.7 & $74.3(72.5-74.8)$ & $72.5(68.6-73.8)$ & 71.7 (71.1-72.4) \\
\hline RFL & $56.0(55.0-57.1)$ & $58.4(54.3-65.0)$ & $58.0(55.2-60.7)$ & $57.4(56.2-59.2)$ & $64.5(54.1-73.9)$ & 59.9 & $59.2(58.5-60.9)$ & $54.9(52.4-58.6)$ & $56.6(56.1-57.2)$ \\
\hline RIMTL & $4.5(3.8-5.3)$ & $4.2(3.8-5.1)$ & $4.2(3.9-4.4)$ & $3.7(3.4-5.3)$ & $4.0(3.7-4.9)$ & 3.7 & $4.5(4.1-4.7)$ & $4.1(3.9-4.1)$ & $4.3(4.3-4.4)$ \\
\hline R3FDW & $3.8(3.5-4.0)$ & $3.6(2.9-4.3)$ & $3.8(3.7-4.2)$ & $4.0(3.7-4.4)$ & $3.5(3.2-3.7)$ & 3.4 & $3.4(3.3-4.2)$ & $2.8(2.8-3.0)$ & $3.3(3.2-3.5)$ \\
\hline R4TDW & $3.4(3.2-3.5)$ & $3.6(2.7-4.3)$ & $3.7(3.2-3.9)$ & $3.3(3.2-4.0)$ & $3.8(3.0-3.9)$ & 3.4 & $3.5(3.3-3.9)$ & $3.1(3.0-3.3)$ & $3.7(3.7-3.7)$ \\
\hline
\end{tabular}

diameter (7.3-9.8\% vs. 4.9-6.1\%), upper eyelid width $(9.8-10.1 \%$ vs. $9.2-9.5 \%)$, and forelimb length $(72.0-73.8 \%$ vs. $65.4-69.4 \%)$, but smaller values in head width $(31.4-34.0 \%$ vs. $34.3-35.0 \%)$ and foot length $(55.0-57.1 \%$ vs. 58.5-60.9\%). Although a female paratype (KUHE 53912) lacks dark markings on dorsum, other paratype specimens have several dark spots on the head like the holotype.

\section{Eggs}

The average diameters of ovarian eggs $(n=$ 10 ) and the ovum numbers of an ovary (about half of the clutch size) were $2.54 \pm 0.07$ (mean \pm 2SE) $\mathrm{mm}$ and 260 (KUHE 48562), $2.02 \pm 0.05$ and 278 (KUHE 53912), and 2.26 \pm 0.04 and 290 (KUHE 54464), respectively. Egg mass estimated from the ovary mass was shown in Fig. 7. The animal pole is black and the vegetal pole is pale yellow brown in color.

\section{Larvae}

Fifty-nine tadpoles of stages (Gosner, 1960) 25 to 41 from the type locality and Ranchan were examined in detail (Fig. 8A, Tables 3, 4). Head-body oval, broadly rounded at snout, flat below, HBW maximum at level of spiracle, 60.9$69.1($ median $=64.8) \%$ of HBL; depth 39.3-56.3 (median = $52.5) \%$ of HBW; eyes dorsolateral, not visible from below, pointing outward, eyeball $11.3-14.3$ (median $=12.8$ ) \% of HBL; interorbital 224.8-286.6 (median $=247.8) \%$ of eye diameter; eye-snout distance 35.7-46.1 (median $=41.5) \%$ of $\mathrm{HBL}$; nostril open, rim not raised, closer to eye than to tip
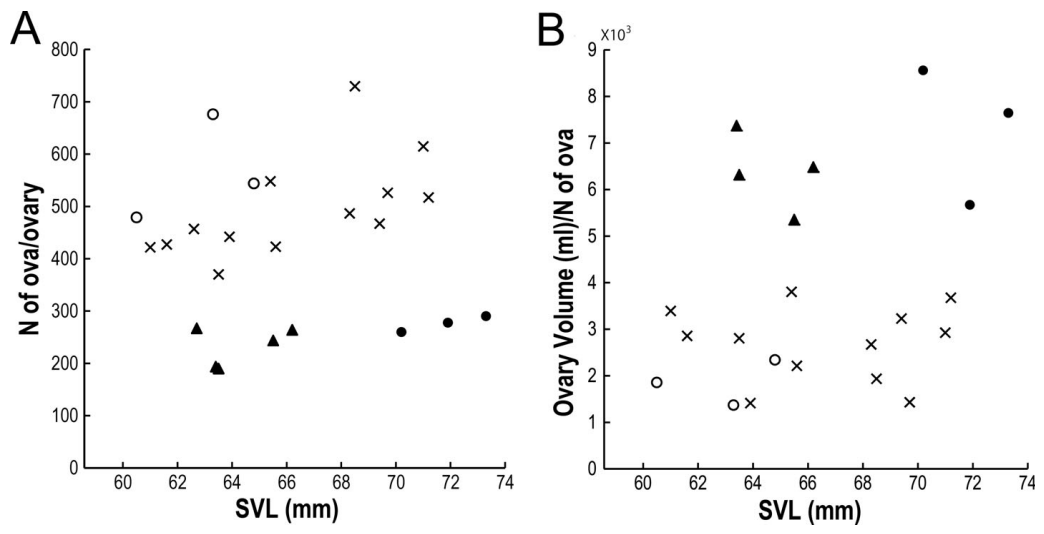

Fig. 7. Plots of oval numbers per ovary (A) and ovum volume (ovary volume divided by oval number) (B) against female SVL. Closed circles $=$ Meristogenys penrissenensis sp. nov., open circles $=M$. jerboa, closed triangles $=M$. amoropalamus, crosses $=$ M. dyscritus.

of snout; internarial $48.4-62.1$ (median $=56.2) \%$ of interorbital.

Oral disk ventral, width $39.7-50.9$ (median $=45.3) \%$ of HBW; upper lip separated from snout by a groove; upper lip with a single row of papillae except for middle third, with a second, shorter inframarginal row of larger papillae near corner; keratodont formula $7(4-7) / 8(1)$ in many individuals, although most of them showed a blank/blanks in the outermost row of keratodont on lower jaw; a specimen of stage 41 has five pairs of divided rows on the upper jaw [8(4-8)], while two specimens of stages 35 and 36 have five rows on left half of upper jaws and four rows on right; some specimens have $6(1), 7(1)$, or $9(1)$ rows of keratodont on lower 
jaw; both jaw sheaths (beaks) heavy, divided, and strongly ribbed; sheaths completely black though outer margins of upper covered with skin; margin coarsely serrate, 4-10 (median $=7$ ) serrae on each half of upper sheaths; 3-7 (median $=6$ ) serrae on each half of lower sheaths; base of upper sheaths M-shaped, lower V-shaped; a large suctorial abdominal disk following oral disk; transverse band of horny tissue present behind oral disk; length 40.7-52.2 (median = 45.8 )\% of $\mathrm{HBL}$; width 81.6-100.0 (median $=91.5$ )\% of HBW.

Spiracle sinistral; tube moderately long, length subequal to length of eyeball, pointing upward and backward, free of body wall for one-third of its length; anal tube median, free of tail; tail heavily muscled, dorsal margin strongly convex, deepest at middle, tapering to pointed tip; tail length 156.2-

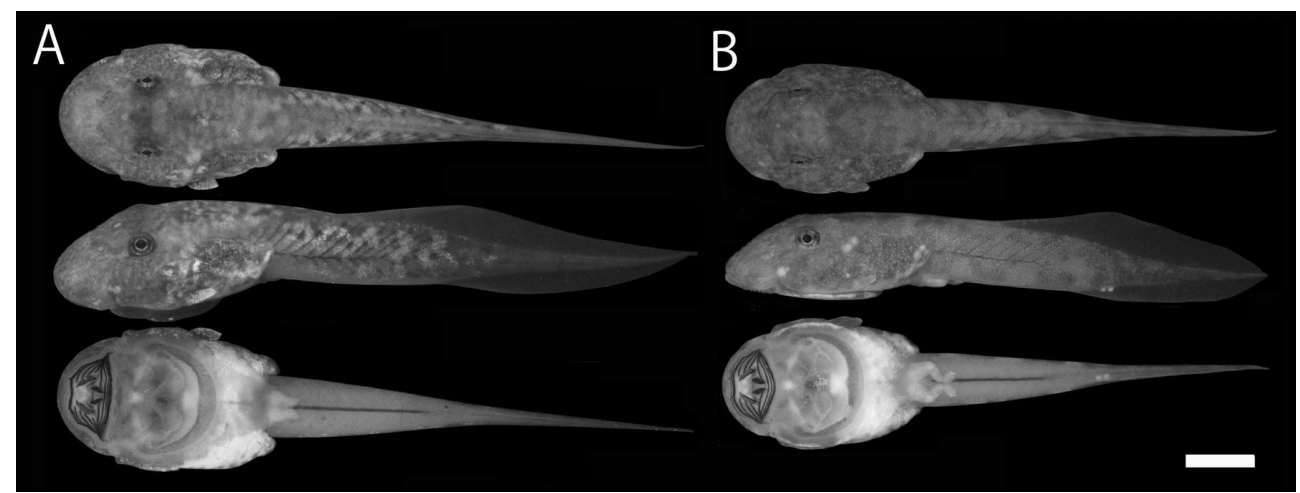

Fig. 8. Dorsal, lateral, and ventral views (from top to bottom) of larval M. penrissenensis sp. nov. (A) and $M$. jerboa $(B)$ collected at a same stream on Mt. Penrissen. Scale bar $=10 \mathrm{~mm}$.
202.7 (median $=181.1) \%$ of HBL; maximum depth 21.8 30.3 (median $=24.0$ ) $\%$ of length (tail measurements made in only specimens with complete tails); caudal muscle deeper than fins in basal half; dorsal fin origin behind body, fin deeper than ventral fin except in final fifth; ventral fin origin at end of proximal half of tail; head-body with four pairs of glandular clusters; an infraorbital cluster with 0-5 (median $=1$ ) glands, ventrolaterally below eye; a prespiracular cluster with 0-5 (median $=1$ ) glands; a postorbital cluster with 1-4 (median $=2$ ) glands, laterally behind eye; a posterior midlateral cluster with 0-11 (median = 3) glands, laterally at end of body; no abdominal cluster; tail without dorsal and ventral fin clusters; head-body covered dorsally with minute keratinized spinules (surface projections), though some of younger specimens (stages $<36$ ) have such spinules only on their head; lateral line pores indistinct.

Color (in life) yellowish brown on head-body and tail, with black spots on body and caudal muscle; both fins without marking except for a fine, dark network. Color (in alcohol) of head-body brown dorsally and laterally, sometimes scattered with small, black spots dorsally; caudal muscle lighter with dark mottling.

\section{Comparisons}

Meristogenys penrissenensis sp. nov. shares mor-

Table 3. Comparisons of total length (TTL) and head-body length (HBL; means $\pm 2 S E$, followed by specimen numbers in parenthesis and ranges, in $\mathrm{mm}$ ) and percentage ratios $(\mathrm{R})$ of each of the other character dimensions to HBL (medians, followed by ranges in parenthesis) in larval Meristogenys penrissenensis sp. nov. and M. jerboa.

\begin{tabular}{|c|c|c|c|c|c|c|c|}
\hline & \multicolumn{2}{|c|}{ M. penrissenensis } & \multicolumn{5}{|c|}{ M. jerboa } \\
\hline & Mt. Penrissen & Ranchan & Mt. Penrissen & Ranchan & Annah Rais & Matang & Santubong \\
\hline \multicolumn{8}{|l|}{ TTL } \\
\hline Stage 25 & 26.3 (2) $23.8-28.8$ & - & - & - & - & 24.0 (2) 24.0-24.1 & - \\
\hline Stage $26-29$ & $34.4 \pm 3.1$ (8) 25.6-39.9 & $39.0(1)$ & - & $25.0(1)$ & 25.1 (2) 22.3-27.9 & - & 27.2 (3) $25.8-29.0$ \\
\hline Stage $30-33$ & $43.1 \pm 1.8(8) 39.1-47.3$ & $40.4(1)$ & - & $30.0 \pm 1.3(6) 27.2-32.0$ & $27.0 \pm 1.9(6) 23.7-30.8$ & - & 31.7 (2) 30.3-33.1 \\
\hline Stage $34-37$ & $48.0 \pm 1.6$ (14) $42.8-52.7$ & - & - & $33.8 \pm 1.2(11) 30.6-36.7$ & $38.0(1)$ & - & 30.7 (2) 26.6-34.7 \\
\hline Stage $38-41$ & $52.0 \pm 1.0(21) 49.2-59.0$ & $47.0(1)$ & $43.6 \pm 2.2$ (5) 39.4-46.1 & $39.0(2) 38.1-40.0$ & 38.0 (2) $35.1-40.9$ & - & - \\
\hline \multicolumn{8}{|c|}{$\mathrm{HBL}$} \\
\hline Stage 25 & 9.6 (2) 8.9-10.3 & - & - & - & - & 9.4 (2) 9.3-9.5 & - \\
\hline Stage $26-29$ & $12.4 \pm 0.7$ (9) 10.9-13.7 & $14.1(1)$ & - & $10.0(1)$ & 10.7 (2) 10.1-11.3 & - & 11.2 (3) $10.9-11.4$ \\
\hline Stage $30-33$ & $14.9 \pm 0.8(9) 12.0-16.1$ & $14.9(1)$ & - & $11.9 \pm 0.4(6) 11.1-12.6$ & $11.1 \pm 0.5$ (6) 10.2-12.0 & - & 13.2 (2) $12.4-13.9$ \\
\hline Stage $34-37$ & $17.2 \pm 0.4$ (14) $16.2-18.7$ & - & - & $13.1 \pm 0.4$ (11) $12.0-14.4$ & $14.4(1)$ & - & 12.7 (2) $11.3-14.0$ \\
\hline Stage $38-41$ & $18.4 \pm 0.3(21) 17.5-19.7$ & $15.9(1)$ & $15.8 \pm 0.8(5) 14.8-16.5$ & 14.5 (2) 14.3-14.7 & 14.4 (2) $14.2-14.6$ & - & - \\
\hline RHBW & $64.8(60.9-69.0)$ & $66.8(64.1-69.1)$ & $65.8(64.9-71.1)$ & $66.0(60.4-70.1)$ & $66.6(63.7-71.5)$ & $64.6(64.3-64.9)$ & $65.7(62.5-68.1)$ \\
\hline RHBD & $33.7(26.4-37.1)$ & 34.3 (33.9-38.2) & $35.2(34.0-36.4)$ & $33.9(28.9-37.3)$ & 34.7 (31.5-38.2) & $30.7(27.2-34.1)$ & $35.2(31.5-37.9)$ \\
\hline RSUW & $59.6(54.4-67.0)$ & $57.2(56.3-58.7)$ & $61.0(56.6-65.1)$ & $57.5(53.4-63.0)$ & $60.0(55.0-62.7)$ & $62.5(62.5-62.6)$ & $60.5(58.2-63.7)$ \\
\hline RSUL & $46.1(40.6-52.1)$ & $44.6(42.9-44.7)$ & $47.1(43.3-51.6)$ & $43.8(40.0-47.8)$ & $45.0(41.5-49.5)$ & - & $43.1(42.4-47.5)$ \\
\hline RSSL & $76.3(67.1-82.0)$ & $71.1(71.1-73.5)$ & $74.2(73.6-83.8)$ & $73.2(70.0-80.3)$ & $75.2(71.6-78.4)$ & 78.7 (78.2-79.2) & 73.4 (70.7-78.2) \\
\hline RODW & $45.3(39.7-53.5)$ & $45.6(43.3-45.6)$ & $39.8(35.8-42.7)$ & $42.9(38.2-47.9)$ & $42.3(36.6-45.2)$ & $46.5(44.2-48.8)$ & $44.3(40.7-46.7)$ \\
\hline RSNW & $51.6(46.8-60.9)$ & $53.0(50.9-53.3)$ & $47.7(38.6-52.3)$ & $49.4(46.7-52.4)$ & $48.5(45.7-51.3)$ & $56.5(55.4-57.5)$ & $50.4(47.4-52.6)$ \\
\hline RED & $12.7(11.5-14.3)$ & $11.4(11.3-12.7)$ & $12.5(10.8-13.7)$ & $13.4(12.5-14.4)$ & $13.2(12.5-14.0)$ & $15.2(14.9-15.5)$ & $13.2(12.8-14.3)$ \\
\hline RESD & $41.1(35.7-46.1)$ & $43.3(41.7-44.2)$ & $39.1(37.0-40.4)$ & $40.6(37.1-43.7)$ & $43.3(41.7-45.7)$ & $44.0(42.7-45.4)$ & $43.1(41.0-48.6)$ \\
\hline RIND & $17.9(15.7-20.3)$ & $17.6(16.7-18.1)$ & $18.4(16.6-20.3)$ & $17.8(17.0-20.3)$ & $19.4(16.8-20.8)$ & $20.1(19.3-21.0)$ & $18.3(16.4-18.5)$ \\
\hline RIOD & $32.0(29.3-34.4)$ & $31.5(31.5-32.0)$ & 33.5 (32.1-38.8) & $33.3(32.0-34.9)$ & $35.0(33.6-36.5)$ & $31.8(31.4-32.2)$ & $31.8(29.3-36.2)$ \\
\hline RTLD & $43.7(39.8-52.4)$ & $46.5(45.1-46.9)$ & $43.9(41.7-49.2)$ & $43.3(38.0-48.0)$ & $46.5(43.3-48.6)$ & $31.8(31.8-31.9)$ & 39.5 (36.6-43.5) \\
\hline RTLL & $181.0(156.1-202.7)$ & $176.2(171.1-195.5)$ & $176.3(165.5-193.2)$ & $155.5(140.7-173.8)$ & $147.1(132.3-180.1)$ & $151.8(151.8-151.8)$ & $138.1(135.3-156.6)$ \\
\hline
\end{tabular}


Table 4. Summary of larval characters in two Meristogenys species examined in this study.

\begin{tabular}{|c|c|c|c|c|c|c|c|}
\hline & \multicolumn{2}{|c|}{ M. penrissenensis } & \multicolumn{5}{|c|}{ M. jerboa } \\
\hline & Mt. Penrissen & Ranchan & Mt. Penrissen & Ranchan & Annah Rais & Matang & Santubong \\
\hline$n$ & 56 & 3 & 5 & 21 & 11 & 2 & 7 \\
\hline Stage & $25-41$ & $28-40$ & $38-40$ & $29-40$ & $27-40$ & 25 & $27-37$ \\
\hline Surface projection & Absent in young & Present & Present & Present & Present & Present & Present \\
\hline Keratodont formulae & $7(4-7) / 8(1)^{*}$ & $7(4-7) / 8(1)$ & $6(4-6) / 7(1)$ & $\begin{array}{c}6(4-6) / 6(1) \\
-6(4-6) / 8(1)\end{array}$ & $\begin{array}{c}6(4-6) / 6(1) \\
-6(4-6) / 7(1)\end{array}$ & $\begin{array}{c}6(4-6) / 7(1) \\
-6(4-6) / 8(1)\end{array}$ & $\begin{array}{c}6(4-6) / 7(1) \\
-6(4-6) / 8(1)\end{array}$ \\
\hline \multicolumn{8}{|l|}{ Jaw sheath serrae } \\
\hline Upper & $3-10$ & $6-7$ & 9 & $6-9$ & $6-9$ & 7 & $6-8$ \\
\hline Lower & $3-7$ & $5-6$ & $7-9$ & $5-7$ & $6-7$ & 6 & $5-7$ \\
\hline \multicolumn{8}{|l|}{ Glands } \\
\hline Infraorbital & $0-5$ & $1-2$ & $1-2$ & $0-3$ & $1-3$ & $1-2$ & $1-2$ \\
\hline Postorbital & $1-4$ & $1-2$ & $0-2$ & $1-3$ & $2-2$ & $2-2$ & $2-3$ \\
\hline Prespiracular & $0-5$ & $0-1$ & $0-1$ & $0-1$ & $0-2$ & $1-1$ & $1-2$ \\
\hline Midlateral & $0-11$ & $0-4$ & $3-5$ & $0-6$ & $2-6$ & $3-3$ & $2-5$ \\
\hline Ventral fin & 0 & 0 & $1-8$ & $0-12$ & $1-11$ & $5-6$ & $0-10$ \\
\hline
\end{tabular}

* Though many specimens have keratodont formulae $7(4-7) / 8(1)$, some have $8(4-8)$ rows on upper jaws or $6(1), 7(1)$, and 9 (1) rows on the lower jaws (see text).

Table 5. Diagnostic characters separating 12 species of the Meristogenys jerboa species group. Character states are as follows: 1-male body size in SVL (S: small [SVL rarely over $41 \mathrm{~mm}$ ], L: large [SVL usually over $41 \mathrm{~mm}$ ]); 2-pattern of rear of thigh (D: dusted with small irregular light dots, B: blotched with large clear light spots, M: mottled with light spots, less clearer than B); 3-amount of ventral pigmentation on ventral surface of tibia (A: heavy pigmentation over entire ventral surface, B: patches with melanophores forming continuous bands or spots across surface, C: isolated, scattered melanophores, D: wide, longitudinal strip clear of melanophores); 4-excision of web between fourth and fifth toes relative to subarticular tubercles of fourth toe (A: excision to proximal edge of distal subarticular tubercle, B: between distal and middle subarticular tubercle, C: distal edge of middle tubercle, D: center of middle tubercle, E: proximal edge of middle tubercle); 5-extent of broad web (-: not extending beyond outermost tubercle of fourth toe, +: reaching disk of fourth toe); 6-black marking on flank region (-: absent [no color difference between above and below dorsolateral line], +: present [color below dorsolateral line clearly darker than those above the line], see Fig. 5); 7-Head width (HW) (N: normal [HW/SVL less than 0.36], W: extremely wide [HW/SVL 0.37]); 8-Eye length (EL) (N: normal [EL subequal to, or shorter than snout length], L: extremely long [EL far exceed snout length]); 9-large black spots on upper lip (-: absent, +: present), 10-pattern of upper iris (G: vivid yellowish green, GY: slightly greenish yellow, Y: yellowish brown to golden without greenish tone), 11-reddish brown color of iris (1: restricted to anterior and posterior part of iris, 2: covering entire part of lower iris, see Fig. 6).

\begin{tabular}{lccccccccccccc}
\hline \multicolumn{1}{c}{ Species } & 1 & 2 & 3 & 4 & 5 & 6 & 7 & 8 & 9 & 10 & 11 & \multicolumn{1}{c}{ References } \\
\hline$M$. amoropalamus & $\mathrm{S}$ & $\mathrm{D}$ & $\mathrm{A}$ & $\mathrm{D}-\mathrm{E}$ & - & - & $\mathrm{N}$ & $\mathrm{N}$ & - & $\mathrm{G}$ & 2 & Matsui (1986), Shimada et al. (2011b) \\
$M$. dyscritus & $\mathrm{S}$ & $\mathrm{D}$ & $\mathrm{A}$ & $\mathrm{D}-\mathrm{E}$ & - & - & $\mathrm{N}$ & $\mathrm{N}$ & - & $\mathrm{Y}$ & 2 & Shimada et al. (2011b) \\
$M$. jerboa & $\mathrm{S}$ & $\mathrm{B}-\mathrm{M}^{* 1}$ & $\mathrm{C}-\mathrm{D}$ & $\mathrm{A}-\mathrm{C}$ & + & + & $\mathrm{N}$ & $\mathrm{N}$ & - & $\mathrm{Y}$ & 2 & Inger and Gritis (1983), This study \\
$M$. macrophthalmus & $\mathrm{S}$ & $\mathrm{M}$ & $\mathrm{C}$ & $\mathrm{C}$ & + & - & $\mathrm{W}$ & $\mathrm{L}$ & - & $?$ & $?$ & Matsui (1986) \\
$M$. maryatiae & $\mathrm{S}$ & $\mathrm{M}$ & $\mathrm{D}$ & $\mathrm{A}-\mathrm{B}$ & + & - & $\mathrm{N}$ & $\mathrm{N}$ & - & $\mathrm{Y}$ & $1^{* 2}$ & Matsui et al. (2010) \\
$M$. orphnocnemis & $\mathrm{S}$ & $\mathrm{M}^{* 3}$ & $\mathrm{~A}-\mathrm{B}^{* 3}$ & $\mathrm{C}-\mathrm{E}^{* 3}$ & + & - & $\mathrm{N}$ & $\mathrm{N}$ & - & $\mathrm{GY}$ & $?^{* 3}$ & Matsui (1986) \\
$M$. penrissenensis & $\mathrm{S}$ & $\mathrm{M}$ & $\mathrm{C}-\mathrm{D}$ & $\mathrm{A}-\mathrm{B}$ & + & - & $\mathrm{N}$ & $\mathrm{N}$ & - & $\mathrm{Y}$ & 1 & This study \\
$M$. phaeomerus & $\mathrm{S}$ & $\mathrm{D}$ & $\mathrm{C}-\mathrm{D}$ & $\mathrm{A}-\mathrm{C}$ & + & - & $\mathrm{N}$ & $\mathrm{N}$ & - & $?^{* 4}$ & 2 & Inger and Gritis (1983) \\
$M$. poecilus & $\mathrm{L}$ & $\mathrm{B}$ & $\mathrm{C}-\mathrm{D}$ & $\mathrm{A}-\mathrm{B}$ & + & - & $\mathrm{N}$ & $\mathrm{N}$ & - & $?^{* 4}$ & 1 & Inger and Gritis (1983) \\
$M$. stenocephalus & $\mathrm{L}$ & $\mathrm{D}$ & $\mathrm{A}$ & $\mathrm{B}$ & + & - & $\mathrm{N}$ & $\mathrm{N}$ & - & $\mathrm{GY}-\mathrm{Y}$ & $1 / 2^{* 5}$ Shimada et al. (2011a) \\
$M$. stigmachilus & $\mathrm{L}$ & $\mathrm{D}$ & $\mathrm{A}$ & $\mathrm{C}$ & + & - & $\mathrm{N}$ & $\mathrm{N}$ & + & $\mathrm{GY}-\mathrm{Y}$ & 1 & Shimada et al. (2011a) \\
$M$. whiteheadi & $\mathrm{L}$ & $\mathrm{D}$ & $\mathrm{A}-\mathrm{B}$ & $\mathrm{C}-\mathrm{E}$ & + & - & $\mathrm{N}$ & $\mathrm{N}$ & - & $\mathrm{GY}-\mathrm{Y}$ & 1 & Shimada et al. (2011a)
\end{tabular}

*1: Inger and Gritis (1983) classify thigh pattern of $M$. jerboa as "B", but many specimens of this species have less clearer pattern than those of $M$. poecilus, and should be classified as "M" in our category. *2: Iris of $M$. maryatiae is described as "iris unicolored, upper and lower halves golden", but judging from the photos of the type series, it is clear that golden area is bordered by reddish brown in between; * 3 : In our unpublished data, we have found intraspecific variations in characters 2, 3, 4, 10, and 11 of $M$. orphnocnemis, but in this table, we just followed the data shown by Matsui (1986). * 4 : In the original description, upper iris of $M$. phaeomerus and M. poecilus is just written as "golden" and "brown", respectively, and we could not classify it to either of our categories. * 5 : At the type locality (Ulu Senagan), only "1" was found, whereas only "2" was observed in another locality (Ulu Kimanis). 
phological characters with the species of the $M$. jerboa species group (Matsui, 1986), and clearly differs from another congeneric species, M. kinabaluensis (Inger, 1966), which lacks outer metatarsal tubercles, having relatively short hindlimb (TL/SVL < 0.7) and dark green body color (vs. outer metatarsal tubercle present, TL/SVL $>0.7$, and pale brown in body color in $M$. penrissenensis). Diagnostic characters separating species of the $M$. jerboa species group including $M$. penrissenensis is shown in Table 5.

When compared with adults of eleven hitherto named species of the M. jerboa species group (Shimada et al., 2011b), M. penrissenensis with SVL of $39.4 \mathrm{~mm}$ in males and 70.2-73.3 $\mathrm{mm}$ in females can be distinguished by smaller body size from M. poecilus (Inger and Gritis, 1983) (34-52 mm, usually over $40.9 \mathrm{~mm}$, in males and 60-78 mm, usually over $68.9 \mathrm{~mm}$, in females), M. stigmachilus Shimada, Matsui, Yambun, and Sudin, 2011 (43.3-50.0 mm in males and 69.2-79.6 mm in females), M. stenocephalus Shimada, Matsui, Yambun, and Sudin, 2011 (48.0-60.4 mm in males and $76.5-86.6 \mathrm{~mm}$ in females), and $M$. whiteheadi (Boulenger, 1887) (39.4-51.0 $\mathrm{mm}$ in males and 71.2-81.6 $\mathrm{mm}$ in females).

Meristogenys penrissenensis can also be differentiated from these larger species by having complicated mottled pattern on the rear of thigh (vs. M. poecilus has much larger and clearer light blotches, and $M$. stenocephalus, $M$. stigmachilus, and $M$. whiteheadi have thighs dusted with small irregular light dots), uniform light brown pattern on the upper lip (vs. M. stigmachilus has large black patches on the upper lip), and only a few dot of melanophores on ventral surface of male tibia (vs. whitish with dense dots of melanophores in $M$. stenocephalus and $M$. stigmachilus, and whitish with patches of pigmentation in $M$. whiteheadi).

Of the remaining seven species of Meristogenys with a similarly small body, $M$. penrissenensis differs in the following characteristics: (1) Broad web reaching disk of fourth toe, and ventral surface of tibia dotted with only a few melanophores (vs. broad web not extending beyond outermost tubercle of fourth toe, and ventral surface of tibia densely dotted with melanophores in $M$. amoropalamus and $M$. dyscritus); (2) temporal fold only vaguely edged by black line (vs. black marking surrounding eye and tympanum extending to flank region in $M$. jerboa); (3) having a narrow head, width relative to SVL less than 0.36 , and eye diameter smaller than snout length (vs. having a wide head, width relative to SVL 0.37, and very large eye whose diameter far exceeding snout length in $M$. macrophthalmus); (4) ventral surface of tibia with only a few pigmentation, web very well developed, excision between fourth and fifth toes distal to distal edge of middle tubercle (vs. ventral surface of tibia with pigmentation, web poorly developed, excision between fourth and fifth toes usually proximal to distal edge of middle tubercle in M. orphnocnemis); (5) rear of thigh dark brown mottled with irregular light spots (vs. rear of thigh is dark brown, dusted with small light spots in M. phaeomerus); (6) upper and lower one-third of iris yellowish brown, bordered by reddish brown in between (vs. reddish brown covering entire part of lower iris in $M$. amoropalamus, M. dyscritus, M. jerboa, and $M$. phaeomerus). Adult $M$. maryatiae and $M$. penrissenensis are morphologically similar including eye color, although they clearly differ in larval morphology (see below). However, in males, $M$. penrissenensis has smaller eye than snout (SL 0.176 [0.164-0.187] SVL and EL 0.152 [0.149-0.154] SVL) whereas $M$. maryatiae has slightly larger eye than snout (SL 0.164 [0.156-0.178] SVL and EL 0.170 [0.155-0.182] SVL).

In larvae, $M$. penrissenensis is unique in having divided jaw sheaths on the lower jaw and four divided keratodont rows on the upper jaw. Although larvae of $M$. dyscritus, $M$. jerboa, M. phaeomerus, $M$. poecilus, and $M$. orphnocnemis have divided lower jaw sheaths like larval $M$. penrissenensis, they differ from it in having six keratodont rows (three undivided, three divided) on the upper jaw. On the other hand, older larvae of $M$. amoropalamus, $M$. stigmachilus, $M$. stenocephalus, and $M$. whiteheadi have seven keratodont rows (three divided, four undivided) on the upper jaw like larval $M$. penrissenensis, but they differ from it in having an undivided lower jaw sheath. Larval $M$. maryatiae and young larvae of $M$. amoropalamus share keratodont formulae and status of lower jaw sheaths with $M$. penrissenensis, but clearly differ in having glands on tail fins (vs. totally absent in M. penrissenensis).

\section{Range}

The new species is so far known from western Sarawak, western Borneo (East Malaysia): northern slope of Mt. Penrissen and Taman Rekreasi Ranchan Serian. The species ranges in altitude from 60 to $870 \mathrm{~m}$ a.s.l.

\section{Natural history}

At the type locality, we collected several females with mature eggs in their ovaries in late December. Although calls of Meristogenys were frequently heard at the time of collection, a majority of them were thought to be those of $M$. jerboa, because all males found emitting calls were $M$. jerboa, and we collected only two males of $M$. penrissenensis in contrast to 20 males of $M$. jerboa. Larval M. penrissenensis of various developmental stages were collected in late December. During the night, larvae were found adhering to rocks in a stream (width $>5 \mathrm{~m}$ ). Larvae of $M$. jerboa and Ansonia minuta Inger, 1960 were collected in the collecting net simultaneously. Associated species observed near the type locality (altitudes $460 \mathrm{~m}$ a.s.l.) were $A$. minuta, $A$. spinulifer (Mocquard, 1890), Leptophryne bornonica (Tschudi, 1838), Pelophryne signata (Boulenger, 1895), Leptolalax marmoratus Matsui, Zainudin, and Nishikawa, 2014, L. gracilis (Günther, 1872), Megophrys nasuta (Schlegel, 1858), Hylarana picturata (Boulenger, 1920), Limnonectes cf. kuhlii, L. hikidai Matsui and Nishikawa, 2014, M. jerboa, Odorrana hosii (Boulenger, 1891), Staurois guttatus (Günther, 1858), and Philautus sp.

\section{DISCUSSION}

In the present study, we found an unknown Meristogenys, which coexisted with the type species of this genus, M. jerboa at two localities of Sarawak (Mt. Penrissen and Ranchan), and described it as a new species, $M$. penrissenensis sp. nov. These two taxa were found to form a sister clade through phylogenetic analyses, but they were easily identified by adult color patterns and larval morphology. The original description of $M$. jerboa (Günther, 1872) is so simple that can mostly be applied to the new species. However, the 
color pattern of the syntypes described "Upper side of the head and back red, side of the body and head black" in Günther (1872), and "Brown above; sides of head and body darker" in Boulenger (1882), preclude assignation of our new form to $M$. jerboa, because this form is uniformly light brown dorsally and laterally (Fig. 5).

Meristogenys penrissenensis and $M$. jerboa seem to be considerably different in reproductive traits. Although female $M$. penrissenensis has a relatively larger body size than female $M$. jerboa, it has the clutch size no more than half, and egg mass more than twice, of $M$. jerboa. Thus, it is most probable that the female $M$. penrissenensis lays larger and fewer eggs than its sister species $M$. jerboa. This relationship seems to be a trade-off between the size and number of offspring (Bagon et al., 2005). A similar relationship has been reported for the two congeneric species sympatric in Sabah, M. dyscritus and M. amoropalamus (Shimada et al., 2011b), in which female M. amoropalamus lays larger and fewer eggs than does $M$. dyscritus female (Fig. 7). Shimada et al. (2011b) also detected differences in these species in egg color (pigmentations on animal pole absent in $M$. amoropalamus, while abundant in $M$. dyscritus). In amphibians, the unpigmented ova like those of $M$. amoropalamus are known to be deposited in places not exposed to direct sunlight (Duellman and Trueb, 1994). Therefore, the difference in ovum color suggests different microhabitats for spawning in the two species. In contrast, M. penrissenensis and $M$. jerboa did not show difference in egg color, but judging from the large differences in clutch and egg sizes, these two species would differ in reproductive strategies.

In the genetic comparison of $M$. jerboa and $M$. penrissenensis, we detected two mitochondrial DNA lineages in $M$. jerboa, which differed with relatively large genetic distances (p-distance: $2.9 \%$ in $16 \mathrm{~S}$ and $7.2 \%$ in ND1). These lineages in $M$. jerboa co-occurred sympatrically at Mt. Penrissen and Annah Rais. However, because no notable morphological differences have been found in either adults or larvae between these two lineages (Shimada, unpublished data), we treated them as intraspecific mitochondrial variations in this study. A similar situation was reported for a congeneric species $M$. dyscritus from Sabah (Shimada et al., 2008). The species was found to contain two mitochondrial lineages separated with relatively large genetic distances (p-distance: $3.0 \%$ in $16 \mathrm{~S}$ and $5.7 \%$ in ND1), but they exhibited no differences in nuclear gene or morphological characters (Shimada et al., 2008). Shimada et al. (2008) ascribed this mitochondrial variation to the demographic history of this species, such as temporal geographic separation within the species and subsequent secondary contact between them. The intraspecific mitochondrial variation found in $M$. jerboa could also be resulted from such events, but to confirm this, we need more detailed morphological comparison and analyses of nuclear genes using additional specimens.

\section{KEY TO MERISTOGENYS LARVAE}

1. Seven rows of keratodont on upper jaw (three undivided and four divided) 2

Six rows of keratodont on upper jaw (three undivided and three divided).

2. Tail glands present on both fins...
Tail glands either absent or present on ventral fin only ................................................................................. 3 3. Lower jaw sheaths divided by a broad space, subequal to sheaths' height ........................ penrissenensis sp. nov.

Lower jaw sheaths undivided or divided by a quite narrow space, apparently narrower than sheaths' height.............. 4 4. Lower jaw sheaths divided (Although it might seem to be an undivided plate with the naked eye, two plates will be clearly observed under a binocular microscope); sucker very large (SUL more than $59 \%$ of HBL).................. maryatiae

Lower jaw sheath undivided (even under a binocular microscope); sucker moderately large (SUL less than $51 \%$ of $\mathrm{HBL}$ )

.... M. stenocephalus, M. stigmachilus and M. whiteheadi* 5. Lower jaw sheaths undivided; a pair of glands on the posterior end of abdomen.... M. kinabaluensis

Lower jaw sheaths divided by a broad space; no glands on abdomen 6 6. No glands on either fin; head and body without surface projections ................................................. phaeomerus ${ }^{\star \star}$

Ventral fin with glands; head and body with surface projections............................................................................. 7 7. Seven or eight rows of keratodont on lower jaw in developed larvae; surface projections (if present) limited only on head..... M. dyscritus

Six rows of keratodont on lower jaw even in developed larvae; surface projections covering whole head and body in developed larvae

..M. jerboa, M. orphnocnemis, and M. poecilus**. *: Number of glands on ventral fin might be used for further classification. In $M$. stenocephalus, some larvae have no glands on tails, while others have a few (up to six). On the other hand, most of $M$. stigmachilus and $M$. whiteheadi have more than ten glands on ventral fin. However, even in these species, we have several cases of larvae with less than six glands (Shimada et al., 2011a).

**: For keys of $M$. phaeomerus and $M$. poecilus, we followed Inger and Gritis (1983), as no specimens were available for these species.

\section{ACKNOWLEDGMENTS}

State Government of Sarawak, and the Forest Department, Sarawak kindly permitted us to conduct this study. We are grateful to the following for their encouragements and/or permission to conduct research and export specimens, and field companionship: Datu Haji Len Talif Salleh, Haji ali Bin Yusop, Marker Nyogin, Mohd. Shabudin Sabki, Uning, Haji Abang Mohamad Mohtar Bin Abang Pawozan, Paulus Ak Meleng, T. Ichioka, and S. T. Yeo. Our field trip was supported by a Grant-in Aid from MEXT through the JSPS (Field Research, No. 23405014) to M. Matsui, and JSPS research fellowship for young scientist to T. Shimada.

\section{REFERENCES}

Bagon M, Townsend CR, Harper JL (2005) Ecology: From Individuals to Ecosystems. Wiley-Blackwell, Oxford

Boulenger GA (1882) Catalogue of the Batrachia Salientia s. Ecaudata in the collection of the British Museum. Taylor and Francis, London

Boulenger GA (1893) Concluding report on the reptiles and batrachians obtained in Burma by Signor L. Fea, dealing with the collection made in Pegu and the Karin Hills in 1887-88. Ann Mus Civ Genova 2 13: 304-347

Boulenger GA (1912) A Vertebrate Fauna of the Malay Peninsula. 
Reptilia and Batrachia. Taylor and Francis, London

Boulenger GA (1920) A monograph of the South Asia, Papuan, Melanesian, and Australian frogs of the genus Rana. Rec Indian Mus 20: 1-226

Duellman WE, Trueb L (1986) Biology of Amphibians. The Johns Hopkins University Press, Baltimore

de Elera C (1895) Catalogo Sistematico de Toda la Fauna de Filipinas Conocida hasta el Presente. Imprenta del Colegio de Santo Tomas, Manila

Felsenstein J (1985) Confidence limits on phylogenies: an approach using the bootstrap. Evolution 39: 783-791

Gosner K (1960) A simplified table for staging anuran embryos and larvae, with notes on identification. Herpetologica 16: 183-190

Günther ACLG (1872) On the reptiles and amphibians of Borneo. Proc Zool Soc Lond 1872: 586-600

Huelsenbeck JP, Hillis DM (1993) Success of phylogenetic methods in the fourtaxon case. Syst Biol 42: 247-264

Huelsenbeck JP, Ronquist FR (2001) MrBayes: Bayesian inference of phylogenetic trees. Bioinformatics 17: 754-755

Inger RF (1966) The systematics and zoogeography of the Amphibia of Borneo. Fieldiana Zool 52: 1-402

Inger RF (1985) Tadpoles of the forested regions of Borneo. Fieldiana Zool New Ser 26: 1-89

Inger RF, Gritis PA (1983) Variation in Bornean frogs of the Amolops jerboa species group, with description of two species. Fieldiana Zool New Ser 19: 1-13

Inger RF, Stuebing RB (2009) New species and new records of Bornean frogs (Amphibia: Anura). Raffles Bull Zool 57: 527535

Jobb G (2011) TREEFINDER version of March 2011. Munich, Germany. Distributed by the author at www.treefinder.de

van Kampen PN (1923) The Amphibia of the Indo-Australian Archipelago. E J Brill, Leiden

Leaché AD, Reeder TW (2002) Molecular systematics of the eastern fence lizard (Sceloporus undulatus): a comparison of parsimony, likelihood, and Bayesian approaches. Syst Biol 51: 4468

Matsui M (1984) Morphometric variation analyses and revision of the Japanese toads (genus Bufo, Bufonidae). Contrib Biol Lab Kyoto Univ 26: 209-428
Matsui M (1986) Three new species of Amolops from Borneo (Amphibia, Anura, Ranidae). Copeia 1986: 623-630

Matsui M, Shimada T, Liu WZ, Maryati M, Khonsue W, Orlov N (2006) Phylogenetic relationships of the oriental torrent frogs of the genus Amolops and its allies (Amphibia, Anura, Ranidae). Mol Phylogenet Evol 38: 659-666

Matsui M, Shimada T, Sudin A (2010) A new species of Meristogenys from Sabah, Borneo (Amphibia, Anura, Ranidae). Zool Sci 27 61-66

McDiarmid RM, Altig R (1999) Tadpoles: the Biology of Anuran Larvae. University of Chicago Press, Chicago

Shimada T, Matsui M, Sudin A, Maryati M (2007) Identity of larval Meristogenys from a single stream in Sabah, Malaysia (Amphibia: Ranidae). Zool J Linn Soc 151: 173-189

Shimada T, Matsui M, Yambun P, Lakim M, Maryati M (2008) Detection of two cryptic taxa in Meristogenys amoropalamus (Amphibia, Ranidae) through nuclear and mitochondrial DNA analyses. Zootaxa 1843: 24-34

Shimada T, Matsui M, Yambun P, Sudin A (2011a) A taxonomic study of Whitehead's torrent frog, Meristogenys whiteheadi, with descriptions of two new species (Amphibia: Ranidae). Zool J Linn Soc 161: 157-183

Shimada T, Matsui M, Yambun P, Sudin A (2011b) A survey of morphological variation in adult Meristogenys amoropalamus (Amphibia, Anura, Ranidae), with a description of a new cryptic species. Zootaxa 2905: 33-56

Smith MA (1925) Contributions to the herpetology of Borneo. Sarawak Mus J 3: 15-34

Smith MA (1931) The herpetology of Mt. Kinabalu, North Borneo 13,455 ft. Bull Raffles Mus 5: 3-32

Tanabe AS (2010) Kakusan4 version 0.1. Software distributed by the author at http://www.fifthdimension.jp/

Taylor EH (1962) The amphibian fauna of Thailand. Univ Kansas Sci Bull 43: 265-599

Yang D (1991) Phylogenetic systematics of the Amolops group of ranid frogs of Southeastern Asia and the Greater Sunda Islands. Fieldiana Zool New Ser 63: 1-42

(Received December 20, 2014 / Accepted June 2, 2015) 